\title{
PEMETAAN POTENSI EMAS DI KABUPATEN TRENGGALEK BERDASARKAN UMUR BATUAN DAN FORMASI BATUAN
}

\author{
Muhammad Taufik ${ }^{1}$, Ayu Kurnia Permatasari ${ }^{2}$ \\ 1,2Departemen Teknik Geomatika FTSLK-ITS, Kampus ITS Sukolilo, Surabaya, 60111 \\ e-mail : ${ }^{1}$ taufik_m@geodesy.its.ac.id, ${ }^{2}$ ayukurniapermatasari@gmail.com
}

\begin{abstract}
Abstrak
Emas merupakan logam mulia yang memiliki manfaat ekonomis tinggi baik individu, kelompok maupun negara. Potensi ekonomis dilihat dari adanya kegiatan penambangan secara besar-besaran dan mencapai distribusi nasional dengan harga jual yang tinggi. Eksplorasi emas saat ini banyak dilakukan dengan metode pemetaan geologi, parit uji, geokimia tanah atau endapan sungai yang dimaksudkan untuk mengetahui kondisi geologi lokal, melokalisir penyebaran dan menafsirkan model atau tipe pembetukan emas di wilayah bersangkutan. Permasalahan yang muncul adalah pada tahap survei pemetaan lapangan, yang membutuhkan waktu panjang serta biaya yang besar. Aplikasi Sistem Informasi Geografis (SIG) dalam eksplorasi mineral memberikan banyak keuntungan baik dari waktu maupun biaya. Kemampuan menganalisa sistem menjadi karakteristik utama SIG seperti analisa statistik dan klasifikasi raster yang disebut analisis spasial. Hasil pengolahan, peta potensi emas dapat di klasifikasikan menjadi 5 kelas, yaitu sangat tinggi, tinggi, cukup, rendah dan sangat rendah. Hasil analisa daerah berdasarkan formasi batuan yang memiliki tingkat potensi emas sangat tinggi tersebar di beberapa kecamatan dengan luas $48 \%$ dari total luas Kabupaten Trenggalek. Hasil analisa daerah berdasarkan umur batuan yang memiliki tingkat potensi emas sangat tinggi tersebar di beberapa kecamatan dengan luas 63\%dari total luas Kabupaten Trenggalek.
\end{abstract}

Kata Kunci : Potensi Emas, Sistem Informasi Geografis, Metode Skoring

\begin{abstract}
Gold is a precious metal that has high economic benefits both individuals, groups and countries. Economic potential is seen from the existence of mining activities on a large scale and achieve the national distribution with a high selling price. Current gold exploration is mostly done by geological mapping methods, test trenches, soil geochemistry or river sediments intended to determine local geological conditions, localize the distribution and interpret the model or type of gold in the region concerned. The problem that arises is at the stage of field mapping survey, which takes a long time and a big cost. The Geographic Information System (GIS) application in mineral exploration provides many advantages over time and cost. The ability to analyze the system becomes the main characteristics of GIS such as statistical analysis and raster classification called spatial analysis. The results of processing, gold potential map can be classified into 5 classes, which is very high, high, sufficient, low and very low. The result of area analysis based on rock formations that have a very high level of gold potential spread in several districts with $48 \%$ of the total area of Trenggalek Regency. The result of area analysis based on rock age which has very high level of gold potential spread in some districts with $63 \%$ of total area of Trenggalek Regency.
\end{abstract}

Keywords : Geographic Information System, Potential Gold, Scoring Method 


\section{PENDAHULUAN}

Emas merupakan logam mulia yang memiliki manfaat ekonomis tinggi baik individu, kelompok maupun negara. Potensi ekonomis dilihat dari adanya kegiatan penambangan secara besarbesaran dan mencapai distribusi nasional dengan harga jual yang tinggi. Sampai saat ini dalam dunia ekonomi emas pun sebagai acuan kegiatan ekonomi, seperti halnya naik turunnya nilai mata uang dunia

Eksplorasi emas saat ini banyak dilakukan dengan metode pemetaan geologi, parit uji, geokimia tanah atau endapan sungai yang dimaksudkan untuk mengetahui kondisi geologi lokal, melokalisir penyebaran dan menafsirkan model atau tipe pembetukan emas di wilayah bersangkutan .

Permasalahan yang muncul kegiatan pemetaan potensi emas adalah pada tahap survei pemetaan lapangan, yang membutuhkan waktu panjang serta biaya yang besar.

Aplikasi Sistem Informasi Geografis (SIG) dalam eksplorasi mineral memberikan banyak keuntungan baik dari waktu maupun biaya. SIG yang dimanfaatkan ini tidak hanya berfungsi untuk memindahkan atau mentransformasi peta analog ke bentuk digital, tetapi dapat lebih jauh lagi karena sistem ini mempunyai kemampuan untuk mengolah dan menganalisis data yang mengacu pada lokasi geografis menjadi informasi berharga. Aplikasi SIG saat ini sudah berkembang pesat dan didukung dengan teknologi yang semakin cangggih. Kemampuan menganalisa sistem menjadi karakteristik utama SIG seperti analisa statistik dan klasifikasi raster yang disebut analisis spasial. Analisis spasial dalam SIG juga dapat digunakan dalam analisis raster yang menggunakan data raster sebagai sumber dataset. Analisis ini biasanya dilakukan untuk aplikasi analisis kesesuaian lahan, area, dan membantu mengambil keputusan sesuai dengan hasil yang didapatkan.

\section{METODE}

\section{Lokasi Penelitian}

Lokasi penelitian ini mengambil wilayah Kabupaten Trenggalek, berlokasi di $111^{\circ} 24^{\prime}-112^{\circ} 11^{\prime}$ BT dan $7^{\circ} 53^{\prime}-8^{\circ} 34^{\prime}$ LS.

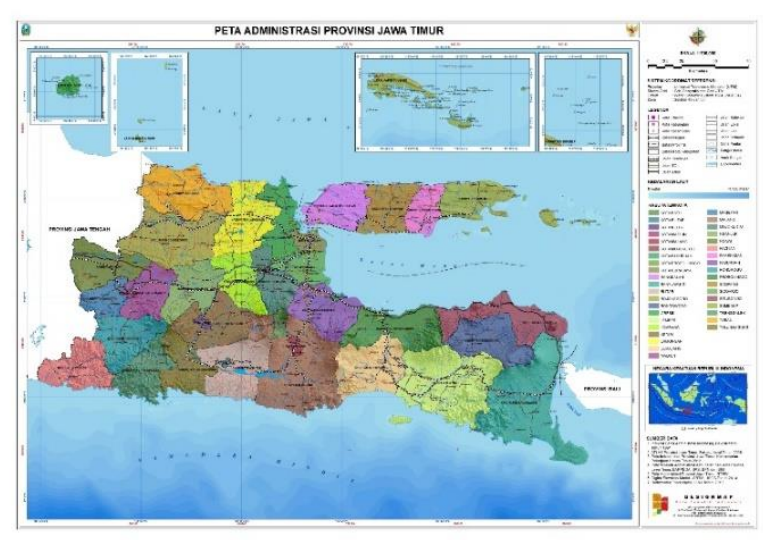

Gambar 1. Lokasi Penelitian (BPS 2012)

\section{Data dan Peralatan}

- Data

Data yang digunakan dalam penelitian ini adalah Peta Geologi Skala 1: 100.000

- Peralatan

Peralatan yang digunakan dalam penelitian ini meliputi Sistem Operasi Pengolahan Data Menggunakan Sistem Informasi Geografis (ArC GIS).

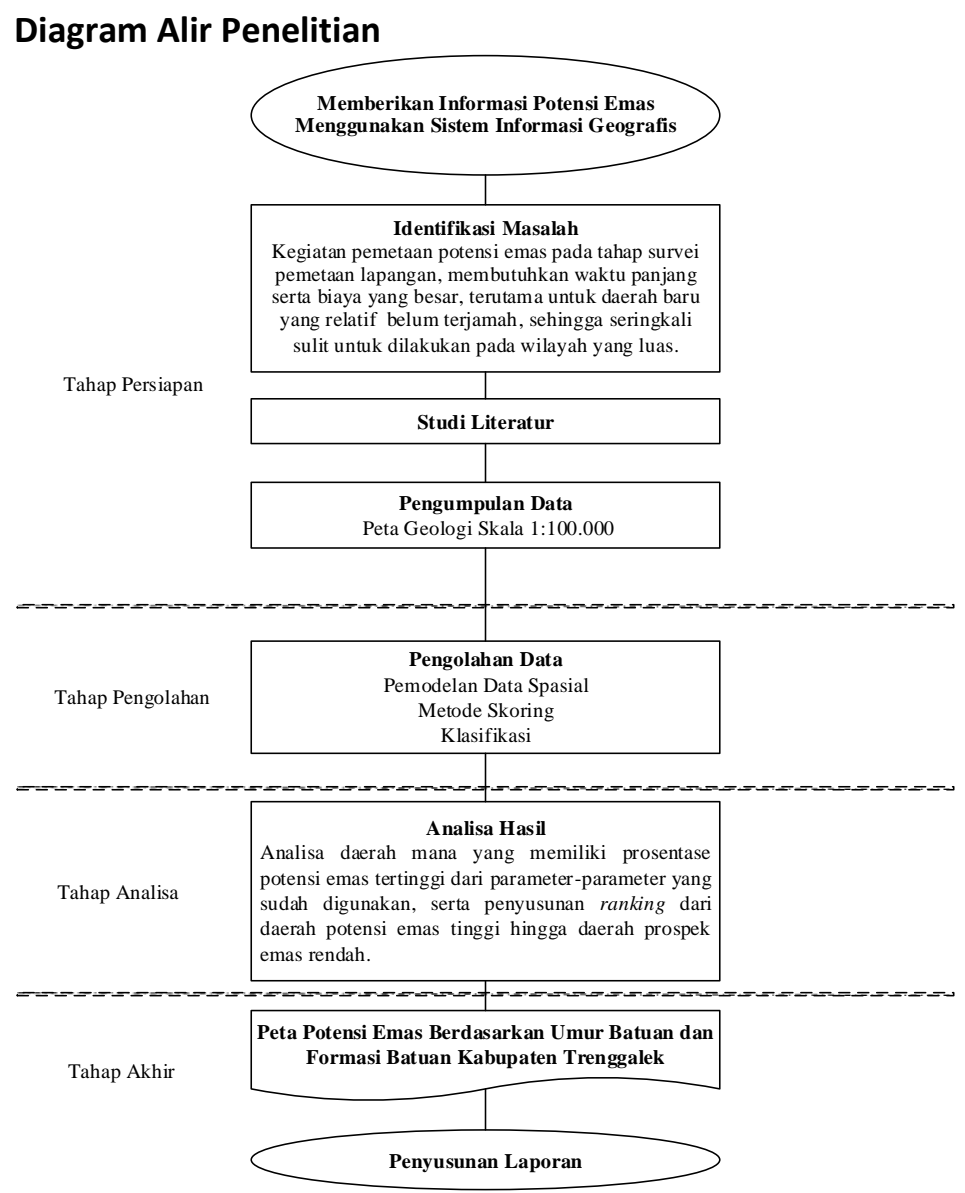

Gambar 1. Diagram Alir Penelitian 
Penjelasan diagram alir tahapan penelitian :

1. Tahap Persiapan

- Identifikasi Masalah

Identifikasi masalah dilakukan untuk menganalisis masalah apa yang terjadi pada daerah penelitian, serta penerapa metode yang dilakukan pada wilayah tersebut. Identifikasi masalah dapat juga berupa pemasalahan dalam penelitian ini yaitu bagaimana memanfaatkan SIG dalam pembuatan peta potensi emas di Kabupaten Trenggalek dengan metode skoring dan overlay yang dapat digunakan untuk menunjang kegiatan eksplorasi.

- $\quad$ Studi Literatur

Studi Literatur dilakukan untuk mempelajari dan mengumpulkan bukubuku referensi dan hasil penelitian sejenis sebelumnya yang pernah dilakukan oleh orang lain yang berkaitan sebagai landasan teori mengenai masalah yang akan diteliti pada tahap pengolahan dari referensi lain yang mendukung baik dari buku, jurnal, majalah, internet dan lain sebagainya.

- Pengumpulan Data

Tahap ini bertujuan untuk mendapatkan data yang akan digunakan dalam penelitian. Pengumpulan data berupa data Peta Geologi Kabupaten Trenggalek.

2. Tahap Pengolahan

Merupakan tahap dimana seluruh data yang telah dikumpulkan kemudian diolah sesuai tujuan dengan berdasarkan referensi yang ada, dengan penyusunan data spasial, metode skoring, pengklasifikasian.

3. Tahap Analisa

Pada tahap ini dilakukan analisa dari hasil pengolahan masing-masing peta yang dapat dilihat dari nilai skor tiap parameter dan faktor dominan yang sekiranya mempengaruhi adanya potensi di suatu daerah. Analisa daerah mana yang memiliki prosentase potensi emas tertinggi dari parameter-parameter yang sudah digunakan, serta penyusunan ranking dari daerah potensi emas tinggi hingga daerah prospek emas rendah.

4. Tahap Akhir

Pembuatan Peta Potensi Emas Berdasarkan Umur Batuan dan Formasi Batuan Kabupaten Trenggalek, serta penyusunan laporan merupakan tahap terakhir dari penelitian ini sebagai laporan penelitian yang berisi dari pelaksanaan penelitian.

\section{HASIL DAN PEMBAHASAN}

\section{Parameter Formasi Batuan}

Pengolahan peta formasi batuan di dapat dari pengolahan data Peta Geologi Kabupaten Trenggalek.

Tabel 1. Klasifikasi Formasi Batuan

\begin{tabular}{ccc}
\hline Parameter Formasi Batuan & Nilai & Tingkat Potensi \\
\hline Batuan Malihan & 6 & Sangat Tinggi \\
BatuanTerobosan & 5 & Tinggi \\
Formasi Arjosari, Nyalindung & 4 & Cukup \\
Formasi Campurdarat, & & \\
$\quad$ Jonggrangan, Oyo, & 3 & Rendah \\
$\quad$ Wonocolo, Wonosari & & \\
Aluvial, Swamp and River & & \\
Deposits, Morfoset & 0 & Sangat Rendah \\
Argohalangan & & \\
\hline
\end{tabular}

Maka hasil plotting klasifikasi tersebut pada peta formasi batuan ditunjukkan pada Gambar 3. Berdasarkan 5 (lima) klasifikasi tingkat potensi, yaitu sangat tinggi, tinggi, cukup, rendah, dan sangat rendah. Hasil dari pengolahan parameter formasi batuan, tingkat potensi sangat tinggi terdapat hampir di seluruh kecamatan di Kabupaten Trenggalek yaitu $48 \%$ dari luas Kabupaten Trenggalek memiliki formasi batuan yang bagus dan kemungkinan besar adanya potensi emas. Karena memang pada dasarnya Jawa Timur bagian selatan memang memiliki formasi batuan yang bagus. 


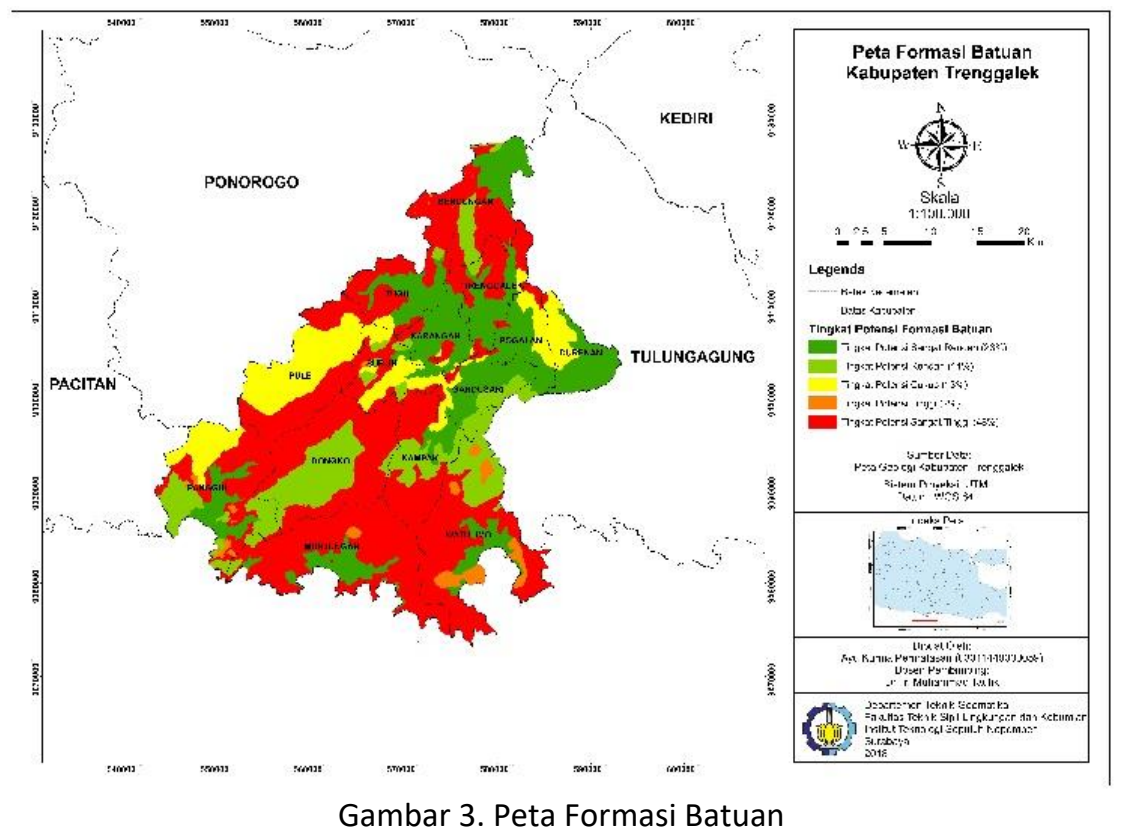

\section{Parameter Umur Batuan}

Pengolahan peta formasi batuan di dapat dari pengolahan data Peta Geologi Kabupaten Trenggalek.

Tabel 2. Klasifikasi Umur Batuan

\begin{tabular}{ccc}
\hline Parameter Umur Batuan & Nilai & Tingkat Potensi \\
\hline Oligo-Miocene & 6 & Sangat Tinggi \\
Lower Miocene & 5 & Tinggi \\
Middle Miocene & 4 & Cukup \\
Upper Miocene, Miocene & 3 & Rendah \\
Upper Pleistocene, Holosen & 0 & Sangat Rendah \\
\hline
\end{tabular}

Maka hasil plotting klasifikasi tersebut pada peta umur batuan ditunjukkan pada Gambar 4 . Berdasarkan 5 (lima) klasifikasi tingkat potensi, yaitu sangat tinggi, tinggi, cukup, rendah, dan sangat rendah. Hasil dari pengolahan parameter umur batuan, tingkat potensi sangat tinggi terdapat hampir di seluruh kecamatan di Kabupaten Trenggalek karena 63\% dari luas Kabupaten Trenggalek memiliki umur batuan yang sudah cukup tua.

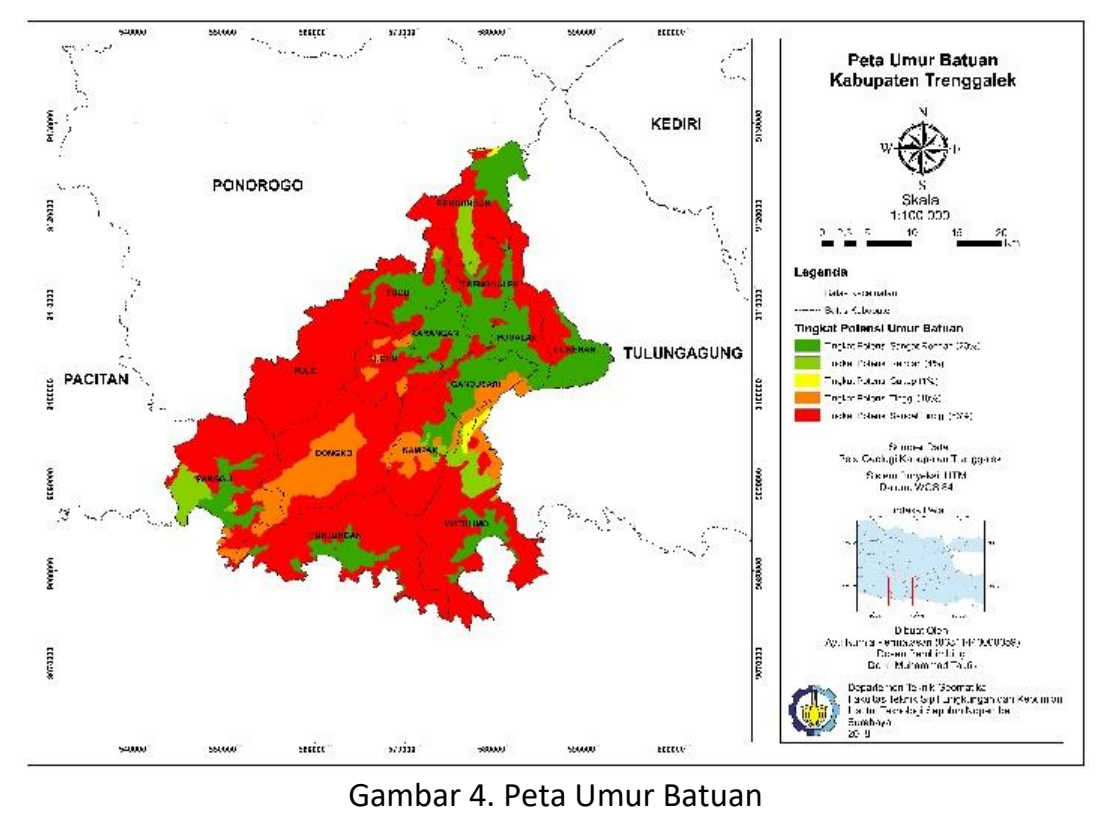




\section{KESIMPULAN}

Berdasarkan pengolahan dan analisis data yang telah dilakukan, berikut adalah kesimpulan yang penulis dapatkan dalam penelitian ini:

1. Peta potensi emas berdasarkan formasi batuan menghasilkan tingkat potensi sangat tinggi, tinggi, cukup, rendah, dan sangat rendah. Hasil dari pengolahan parameter formasi batuan, tingkat potensi sangat tinggi terdapat hampir di seluruh kecamatan di Kabupaten Trenggalek yaitu $48 \%$ dari luas Kabupaten Trenggalek memiliki formasi batuan yang bagus dan kemungkinan besar adanya potensi emas. Karena memang pada dasarnya Jawa Timur bagian selatan memang memiliki formasi batuan yang bagus.

2. Peta potensi emas berdasarkan umur batuan menghasilkan tingkat potensi sangat tinggi, tinggi, cukup, rendah, dan sangat rendah. Hasil dari pengolahan parameter umur batuan, tingkat potensi sangat tinggi terdapat hampir di seluruh kecamatan di Kabupaten Trenggalek karena 63\% dari luas Kabupaten Trenggalek memiliki umur batuan yang sudah cukup tua.

\section{UCAPAN TERIMAKASIH}

Penulis A.K.P. mengucapkan terima kasih kepada PT.ANTAM yang telah menyediakan data untuk keperluan penelitian, Bapak Dr. Ir. Muhammad Taufik selaku dosen pembimbing yang telah memberikan dukungan dan bimbingan selama penelitian dilaksanakan.

\section{DAFTAR PUSTAKA}

Diantoro, Yimi. 2010. Emas: Investasi dan Pengolahannya. Jakarta: Penerbit Gramedia Pustaka Utama.

Sukandarrumidi. 2009. Geologi Mineral Logam. Yogyakarta: Universitas Gajah Mada Press.

Tampubulon, Armin. 2006. Eksplorasi Emas di Kabupaten Kerinci Provinsi Jambi. Proceeding Hasil Kegiatan Lapangan dan Non Lapangan, Pusat Sumberdaya Geologi. 